\title{
Effect of Using Some Soil Conditioners on Salt Affected Soil Properties and Its Productivity at El-Tina Plain Area, North Sinai, Egypt
}

\author{
A. A. Mousa \\ Soil Conservation Dept., Desert Research Center, Cairo, Egypt.
}

TWO FIELD experiments were conducted in El-Tina Plain area, North Sinai, Egypt, to study the effect of biochar and humic acids as nontraditional soil conditioners on some properties of sandy soil as well as the productivity of wheat and corn plants grown on such soil. The two conditioners were applied individually with three rates. The application rates of biochar were 5 , 10 and 20 ton/fed., while the respective rates of humic acids were 5, 10 and $20 \mathrm{~kg} / \mathrm{fed}$.

Results of the present study revealed that the application of all the studied treatments decreased soil bulk density, hydraulic conductivity, $\mathrm{pH}, \mathrm{EC}$, soluble $\mathrm{Na}$, SAR and ESP values, while increased cation exchange capacity, organic matter content, total $\mathrm{N}$ as well as available amounts of $\mathrm{P}, \mathrm{K}, \mathrm{Fe}, \mathrm{Mn}, \mathrm{Zn}$ and $\mathrm{Cu}$ in soil.

Data also indicated that all the treatments significantly increased the grain yields of wheat and corn plants and the treatment (20 kg humic acids/fed.) was the best one. The rate of increment over the control due to such treatment reached 39.49 and $37.68 \%$ for wheat and corn grain yields, respectively. Also, macro and micronutrient concentrations of such grains were significantly increased by increasing the application rates of the applied conditioners.

Based on results of the current study, it can be concluded that using biochar and humic acids as organic conditioners is helpful to improve soil properties, compensate the deficiency of nutrients in soil and have significant effects on the productivity of wheat and corn plants. These materials are easily producible, biodegradable, less expensive, cause no environmental hazards to human health and will be ecologically safe and culturally more acceptable among farmers. So, it can be recommended to use such materials as soil conditioners under salt affected soil conditions.

Keywords: Biochar, Humic acids, Salt affected soils, Corn yield, Wheat, Macro and micronutrients.

\begin{abstract}
Introduction
Salt affected soils occur commonly in arid and semiarid regions and characterized by excessively high levels of water- soluble salts. In most cases, sodium chloride is a major salt contaminant in such soils, it has a small molecule size and when oxidized by water, produces $\mathrm{Na}^{+}$and $\mathrm{Cl}^{-}$ions, which are easily absorbed by the root cells of higher plants and transferred to the whole plant causing ionic and osmotic stresses at the cellular level of such plants, (Rodriguez-Navarro and Rubio, 2006).

Salt toxicity is one of the major factors limiting crop production and environmental quality in saline and/or sodic soils. Excessive
\end{abstract}

amounts of salts adversely affect the physical and chemical properties of soil, microbiological processes and plant growth (Ramoliya and Pandey, 2003 and Pitman \& Läuchli, 2004).

Biochar is the carbonaceous residue left in the pyrolysis process. Several studies have highlighted its benefit for mitigation of global climate change and as an effective strategy to manage soil quality and crop productivity (Renard et al., 2012). Amending soil with biochar has increasingly attracted widespread attention for its chemical stability, ideally suited for sequestrating $\mathrm{C}$ in soil, rapidly increases soil fertility and plant growth by supplying and retaining 
nutrients while simultaneously improving the physical and biological properties of the soil (Woolf et al., 2010 and Uzoma et al., 2011).

Humic acids is produced by the chemical and biological decomposition of organic material. It is an important constituent of soil organic matter which enhances the growth and yield of crops and improves soil physical and chemical characteristics, (Hafez, 2003; Abd El- Al et al., 2005 and Khan et al., 2012). It is particularly used to ameliorate or reduce the negative effects of salt stress. Humic acids contributes to plant growth through its effect not only on the physical and chemical but also on biological properties of the soil. It is mainly a nutritional function, as it serves as a source of $\mathrm{N}, \mathrm{P}$, and cations for plant growth (Arancon et al., 2006).

Several studies have reported the ability of humic acids to increase the growth of different plant species grown under adverse conditions. Some authors suggested that humic acids promote plant growth by improving the bioavailability of certain nutrients, mainly iron and zinc. Others proposed that humic acids can directly influence the plant metabolism by both activating the root plasma membrane ATPase activity and increasing the nitrate uptake rates in roots (Nardi et al., 2002; Chen et al., 2004 ${ }_{\mathrm{a}, \mathrm{b}}$ and Mora et al., 2010 ).

The aim of this study is to evaluate the efficiency of using those nontraditional soil conditioners, $i$. e., biochar and humic acids for improving some properties of salt affected soil as well as raising its productivity of wheat and corn yields.

\section{Materials and Methods}

Two field experiments were conducted in El-Tina Plain, North Sinai, Egypt, to evaluate the efficiency of using biochar and humic acids for improving some properties of salt affected soil as well as raising its productivity of wheat and corn yields. Composite samples representing soil, in which the experiment was carried out, were taken and prepared to determine some properties of such soil (Table 1).

The experimental design was randomized complete block design with three replicates and the experimental treatments were as follows:

TABLE 1. Some physical and chemical properties of the soil under investigation

\begin{tabular}{|c|c|c|c|c|c|c|c|c|}
\hline \multirow{2}{*}{$\begin{array}{l}\text { pH in soil paste } \\
\text { extract }\end{array}$} & \multicolumn{3}{|c|}{ Particle size distribution (\%) } & \multirow{2}{*}{$\begin{array}{l}\text { Texture } \\
\text { class }\end{array}$} & \multirow{2}{*}{$\begin{array}{c}\text { Avail. } \\
\text { soil } \\
\text { water } \\
(\%)\end{array}$} & \multirow{2}{*}{$\begin{array}{c}\text { Bulk } \\
\text { density } \\
(\mathrm{g} / \mathrm{cm} 3)\end{array}$} & \multirow{2}{*}{$\begin{array}{l}\text { H.C. }(\mathrm{m} / \\
\text { day) }\end{array}$} & \multirow{2}{*}{$\begin{array}{c}\text { CEC } \\
\text { (me/100g } \\
\text { soil) }\end{array}$} \\
\hline & Sand & Silt & Clay & & & & & \\
\hline 7.95 & 79.53 & 7.10 & 13.37 & SL & 8.67 & 1.45 & 3.25 & 10.40 \\
\hline \multirow{2}{*}{$\begin{array}{c}\mathrm{EC}(\mathrm{dS} / \mathrm{m}) \text { in soil } \\
\text { paste extract }\end{array}$} & \multicolumn{3}{|c|}{ Soluble cations (me/l) } & \multicolumn{3}{|c|}{ Soluble anions (me/l) } & \multirow{2}{*}{ SAR } & \multirow{2}{*}{ ESP } \\
\hline & $\begin{array}{l}\mathrm{Ca}^{2+}+ \\
\mathrm{Mg}^{2+} \\
\end{array}$ & $\mathrm{Na}^{+}$ & $\mathrm{K}^{+}$ & $\mathrm{HCO}_{3}^{-}$ & $\mathrm{Cl}^{-}$ & $\mathrm{SO}_{4}{ }^{2-}$ & & \\
\hline 4.43 & 20.64 & 21.67 & 2.00 & 10.86 & 28.18 & 5.27 & 6.28 & 7.32 \\
\hline $\mathrm{CaCO} 3(\%)$ & $\mathrm{OM}(\%)$ & Total N (\%) & \multicolumn{6}{|c|}{ Ayailable micronutrients $(\mu \mathrm{g} / \mathrm{g})$} \\
\hline 1.80 & 0.38 & 0.09 & 9.80 & 82 & 11.82 & 15.24 & 0.95 & 1.11 \\
\hline
\end{tabular}

The two conditioners were applied individually. Table 2 depicts some chemical properties of the applied materials.

TABLE 2. Some properties of the applied soil conditioners

\begin{tabular}{|c|c|c|c|c|c|c|c|c|c|c|c|}
\hline \multirow[t]{2}{*}{ Parameters } & \multirow[t]{2}{*}{ pH } & \multirow{2}{*}{$\begin{array}{c}\text { EC } \\
(\mathrm{dS} / \mathrm{m})\end{array}$} & \multirow{2}{*}{$\begin{array}{l}\text { OC } \\
(\%)\end{array}$} & \multicolumn{3}{|c|}{$\begin{array}{c}\text { Total macronutients } \\
(\%)\end{array}$} & \multicolumn{4}{|c|}{ Total micronutients (ug/g) } & \multirow{2}{*}{$\begin{array}{l}\mathrm{C} / \mathrm{N} \\
\text { ratio }\end{array}$} \\
\hline & & & & $\mathrm{N}$ & $\mathrm{P}$ & $\mathrm{K}$ & $\mathrm{Fe}$ & $\mathrm{Mn}$ & $\mathrm{Zn}$ & $\mathrm{Cu}$ & \\
\hline Biochar & 7.4 & 1.5 & 36 & 1.8 & 4.3 & 2.9 & 365 & 190 & 120 & 9 & 20 \\
\hline Humic acids & 6.88 & 1.94 & 34.4 & 2.15 & 2.5 & 3.5 & 418 & 260 & 219 & 21.96 & 16 \\
\hline
\end{tabular}

Egypt. J. Soil Sci. 57, No. 1 ( 2017 ) 
1- Control treatment (without any soil conditioner application).

2- Biochar at the rate of 5 ton/fed.

3- Biochar at the rate of 10 ton/fed.

4- Biochar at the rate of $20 \mathrm{ton} / \mathrm{fed}$.

5- Humic acids at the rate of $5 \mathrm{~kg} / \mathrm{fed}$.

6- Humic acids at the rate of $10 \mathrm{~kg} / \mathrm{fed}$.

7- Humic acids at the rate of $20 \mathrm{~kg} / \mathrm{fed}$.

Seeds of wheat (L.) cv. Sakha 8 at the rates of $70 \mathrm{~kg}$ seeds/fed.were sown on 32015/10/ after the application of soil conditioners to experimental plots (recent application). After wheat harvesting, corn (Zea maize L.) cv. Pioneer $30 \mathrm{~K} 8$ at the rates of $12 \mathrm{~kg}$ seeds/fed.were sown on the same plots on
152016/3/ without soil conditioners application (residual effect).

All plots received $\mathrm{N}, \mathrm{P}$ and $\mathrm{K}$ fertilizers as follows:-

- Superphosphate $\left(15.5 \% \mathrm{P}_{2} \mathrm{O}_{5}\right)$ at the rates of 150 and $200 \mathrm{~kg} \mathrm{P} / \mathrm{fed}$., added before cultivation of both wheat and corn respectively.

- Ammonium nitrate $(33.5 \% \mathrm{~N})$ at the rates of 150 $\mathrm{kg} \mathrm{N} /$ fed., added at two equal doses, one and two months, after cultivation of both wheat and corn, respectively.

- Potassium sulphate $\left(48 \% \mathrm{~K}_{2} \mathrm{O}\right)$ at the rate of 50 $\mathrm{kg} \mathrm{K} /$ fed., for the two cultivated crops added in two equal doses at the same time of $\mathrm{N}$ fertilizer application.

TABLE 3. Chemical composition of the applied irrigation water

\begin{tabular}{|c|c|c|c|c|c|c|c|c|c|c|}
\hline \multirow{2}{*}{$\mathrm{pH}$} & \multirow{2}{*}{$\begin{array}{l}\mathrm{EC} \\
(\mathrm{dS} / \mathrm{m})\end{array}$} & \multicolumn{4}{|c|}{ soluble cations(me/l) } & \multicolumn{4}{|c|}{ soluble anions(me/l) } & \multirow{2}{*}{ SAR } \\
\hline & & $\mathrm{Ca}^{2+}$ & $\mathrm{Mg}^{2+}$ & $\mathrm{Na}^{+}$ & $\mathrm{K}^{+}$ & $\mathrm{CO}_{3}^{2-}$ & $\mathrm{HCO}_{3}^{-}$ & $\mathrm{Cl}^{-}$ & $\mathrm{SO}_{4}^{2-}$ & \\
\hline 7.45 & 2.41 & 4.39 & 8.78 & 10.79 & 0.14 & - & 3.90 & 10.74 & 9.46 & 1.16 \\
\hline
\end{tabular}

The necessary management operations for the two cultivated crops were conducted at the appropriate times. Irrigation water from El-Salam Canal was applied every week and the irrigation was stopped 30 days before harvesting of the two crops. Table 3 presents the chemical composition of such water.

Plants were harvested at maturity, after 150 and 120 days from planting for both wheat and corn respectively, then grain yields were recorded.

Soil samples representing all the treatments were taken after harvesting then air dried, sieved through a $2 \mathrm{~mm}$ and stored for analysis. Also, grain samples represented all the treatments were taken, dried at $70{ }^{\circ} \mathrm{C}$, ground and stored for analysis. Analysis of soil, plant, water and the applied conditioners were determined by the standard methods of (Black, 1982; Cottenie et al., 1982 and A.O.A.C., 1995). The statistical analysis was carried out according to Snedecor and Cochran (1982).

\section{Results and Discussion}

Effect of the applied conditioners on some soil physical and chemical properties:

Data in Table 4 show the effect of the applied treatments on some physical and chemical properties of the investigated soil. Concerning the effect of the applied treatments on soil bulk density and hydraulic conductivity values, data in Table 4 show that their values decreased by increasing the application rates of all the applied conditioners. The highest decreases of such values were associated with the treatment $(20 \mathrm{~kg}$ humic acids/fed.) as the rate of decreases below the control under recent application reached 24.83 and $42.42 \%$ respectively, while the respective values under residual application reached 12.08 and $50.00 \%$. Such decreases in soil bulk density can be attributed to the low specific gravity of organic materials and the role of organic products in enhancing soil aggregation which increases the apparent soil volume and consequently decrease bulk density. These results are in agreement with Tejada and Gonzalez (2006). Also, the improvement or the pronounced decrease in hydraulic conductivity of the studied sandy loam soil may be attributed to the creation of micro pores, and the dominance of meso and micropores on the exposed pore sizes. These results are in agreement with those of El-Fayoumy and Ramadan (2002).

It is also, clear that soil $\mathrm{pH}$ values decreased as a result of all treatment applications. The rate of decrement in soil $\mathrm{pH}$ values below the control treatment reached 2.53 and $2.02 \%$ due to recent and residual applications of 20 ton. biochar/ fed., respectively. The respective values under $20 \mathrm{~kg}$ humic acids/fed. were 5.06 and $5.17 \%$. The positive effect of biochar on reducing soil $\mathrm{pH}$ values may be due to the acidic materials produced from the oxidation and decomposition of such material in soil (Senesi and Plaza, 2007;

Egypt. J. Soil Sci. 57, No. 1 ( 2017 ) 
TABLE 4. Effect of the applied conditioners on some physical and chemical properties of the investigated soil.

\begin{tabular}{|c|c|c|c|c|c|c|c|}
\hline Treatments & Control & \multicolumn{3}{|c|}{ Biochar (ton./fed.) } & \multicolumn{3}{|c|}{ Humic acids (Kg/fed.) } \\
\hline \multicolumn{8}{|c|}{ Bulk density (g/cm3) } \\
\hline Recent application & 1.49 & 1.25 & 1.22 & 1.18 & 1.17 & 1.15 & 1.12 \\
\hline Residual effect & 1.49 & 1.41 & 1.35 & 1.35 & 1.33 & 1.33 & 1.31 \\
\hline \multicolumn{8}{|c|}{ Hydraulic conductivity $\left(\mathrm{cm} / \mathrm{min}^{-1}\right)$} \\
\hline Recent application & 0.33 & 0.27 & 0.23 & 0.28 & 0.24 & 0.21 & 0.19 \\
\hline Residual effect & 0.36 & 0.29 & 0.24 & 0.24 & 0.24 & 0.23 & 0.18 \\
\hline \multicolumn{8}{|c|}{$\mathrm{pH}$} \\
\hline Recent application & 7.90 & 7.85 & 7.79 & 7.70 & 7.74 & 7.55 & 7.50 \\
\hline Residual effect & 7.93 & 7.88 & 7.86 & 7.77 & 7.75 & 7.56 & 7.52 \\
\hline \multicolumn{8}{|c|}{ CEC (me/100g soil) } \\
\hline Recent application & 10.8 & 11.4 & 12.7 & 15.3 & 11.2 & 12.2 & 13.6 \\
\hline Residual effect & 10.6 & 11.1 & 11.9 & 13.8 & 11.1 & 11.7 & 12.5 \\
\hline \multicolumn{8}{|c|}{$\mathrm{EC}(\mathrm{dS} / \mathrm{m})$} \\
\hline Recent application & 4.27 & 3.33 & 2.92 & 2.79 & 3.19 & 2.65 & 2.29 \\
\hline Residual effect & 4.31 & 3.70 & 3.31 & 3.15 & 3.61 & 3.05 & 2.63 \\
\hline \multicolumn{8}{|c|}{ Soluble $\mathrm{Ca}^{2+}+\mathrm{Mg}^{2+}(\mathrm{me} / \mathrm{l})$} \\
\hline Recent application & 19.96 & 14.65 & 15.18 & 15.22 & 16.15 & 13.63 & 11.3 \\
\hline Residual effect & 20.13 & 16.29 & 17.2 & 17.16 & 18.28 & 16.74 & 12.99 \\
\hline \multicolumn{8}{|c|}{ Soluble $\mathrm{Na}^{+}(\mathrm{me} / \mathrm{l})$} \\
\hline Recent application & 20.19 & 16.09 & 12.38 & 11.42 & 13.58 & 12.34 & 11.18 \\
\hline Residual effect & 20.36 & 17.91 & 14.03 & 12.87 & 15.38 & 13.17 & 12.85 \\
\hline \multicolumn{8}{|c|}{ SAR } \\
\hline Recent application & 6.39 & 5.95 & 4.49 & 4.14 & 4.78 & 4.73 & 4.70 \\
\hline Residual effect & 6.42 & 6.27 & 4.78 & 4.39 & 5.09 & 4.55 & 5.04 \\
\hline \multicolumn{8}{|c|}{ ESP } \\
\hline Recent application & 7.53 & 6.97 & 5.08 & 4.61 & 5.46 & 5.39 & 5.36 \\
\hline Residual effect & 7.57 & 7.38 & 5.46 & 4.95 & 5.86 & 5.16 & 5.81 \\
\hline
\end{tabular}

Dias et al., 2010). Biochar is not at all inert in soil and can be oxidized, especially at the surface, through chemical and microbial activity (Cheng et al., 2006, 2008). The slow oxidization of biochar in soils can produce carboxylic functional groups (Brodowski et al., 2005 and Cheng et al., 2006). The formation of the acidic functional groups can neutralize alkalinity and eventually decrease soil $\mathrm{pH}$. These results are in agreement with those found by (Dhanushkodi and Subrahmaniyan, 2012). With respect to soil CEC, data in the same table indicated that soil CEC values increased by increasing the application rate of both conditioners, and biochar treatments were more effective than that of humic acids in this concern. The rate of increment under recent applications of 20 ton biochar/fed. reached $41.67 \%$, while reached $30.19 \%$ for residual effect of such treatment. These increases might be due to the presence of ash in biochar, which helps for Egypt. J. Soil Sci. 57, No. 1 ( 2017 ) the immediate release of the occluded mineral nutrients like $\mathrm{Ca}, \mathrm{K}$ and $\mathrm{N}$ for crop use, Scheuner et al. (2004).

Data in Table 4 also indicate that the soil salinity (EC), soluble $\mathrm{Ca}+\mathrm{Mg}$ and soluble $\mathrm{Na}$ were favorably affected by all the applied treatments. The application of the treatment $(20$ $\mathrm{kg}$ humic acids/fed.) showed the highest decrease in such values as compared with the other treatments. Where their decreases under the recent applications reached 46.37, 43.39 and $44.63 \%$ for $\mathrm{EC}$, soluble $\mathrm{Ca}+\mathrm{Mg}$ and soluble $\mathrm{Na}$ values, respectively. The respective values under residual applications reached $38.98,35.47$ and $36.89 \%$ as compared with the control treatment. The positive effect of humic acids on reducing soil $\mathrm{pH}$ values may be due to its function group that may give it high ability to separate $\mathrm{Na} \mathrm{Cl}$ salt, thus reduces the deleterious effects of salt stress on plants. 
Also, microorganisms used humic acids as carbon source, thus may stimulate microorganisms to produce phytohormones, which play an important role in decline soil salinity (Khalil et al., 2013).

Data in the same table also revealed that SAR and ESP values decreased by the application of all amendments and the biochar treatment (20 ton /fed.) was more effective than all the other treatments in this concern. The rate of decrement under recent applications of such treatment reached 35.21 and $38.78 \%$ for SAR and ESP values, respectively, while the respective values under residual applications were 31.62 and $34.61 \%$ as compared with the control treatment. This was expected since biochar treatments had more soluble $\mathrm{Na}$ than that of humic ones.

\section{Effect of the applied conditioners on soil fertility status}

Soil organic carbon is one of the key indicators of soil quality, data in Table 5 show that soil organic matter content was increased due to all the applied treatments. It is also clear that the soil organic matter content were higher with the application of humic acids to soil than that of biochar ones. This is due to the higher OM content of humic acids relative to the other amendment, (Table 2). The increases in soil organic matter content were more obvious with the higher application rates of both the two conditioners and the best treatment in this concern was the application of ( $20 \mathrm{~kg}$ humic acids /fed.) as the rate of increment over the control reached 97.90 and $69.39 \%$ under recent and residual applications, respectively.

With respect to soil total $\mathrm{N}$, data in the same table indicated that all the applied treatments, especially those of humic acids, increased soil total N. The rate of increment over the control reached 48.21 and $59.18 \%$ due to humic acids application at the rate of $20 \mathrm{~kg} / \mathrm{fed}$. under recent and residual applications, respectively. The respective values for biochar (20 ton/fed.) were 25.89 and $30.61 \%$. This may be due to larger amounts of total $\mathrm{C}$ and $\mathrm{N}$ in the applied conditioners that could provide a larger source of $\mathrm{N}$ for mineralization. These results are in agreement with those obtained by Ebhin Masto, (2013). In this regard, Angelova et al. (2013) stated that there was a strong positive correlation between the total organic carbon content and the total nitrogen content in soil and the application of organic materials might have produced more residual $\mathrm{N}$ in soil as compared with the control.

Data in Table 5 also indicate that the availability of $\mathrm{P}, \mathrm{K}, \mathrm{Fe}, \mathrm{Mn}, \mathrm{Zn}$ and $\mathrm{Cu}$ in soil was greatly enhanced by the application of all the applied treatments. The best treatment in this concern was that of $(20 \mathrm{~kg}$ humic acids / fed.) where the rate of increment over the control reached 126.83, 78.8, 172.74, 190.3, 162.56 and $86.6 \%$ for available $\mathrm{P}, \mathrm{K}, \mathrm{Fe}, \mathrm{Mn}, \mathrm{Zn}$ and $\mathrm{Cu}$ respectively under recent applications, while the respective increases under residual applications reached 98.38, 72.73, 153.68, 128.52, 78.65 and $77.53 \%$. The positive effects of the applied materials on such increases may be attributed to one or more of the following: a) higher initial content of such nutrients in the applied materials, (Table $2, \mathrm{~b}$ ) reduction of soil $\mathrm{pH}$ values resulting from amendment application as found in this study (Table 4, c) slow mineralization process of organic matter, hence release of the nutrients and, d) converting unavailable soil phosphate into available forms due to humic acids application, (Bhattacharjee et al., 2001 and Angelova et al., 2013). The obtained results are in agreement with those reported by Shankar et al. (2012).

Effect of the applied conditioners on grain yield of the investigated plants:

Data in Table 6 indicate that grain yield of wheat and corn plants significantly increased by the application of all the experimental treatments. It is also clear that such increases were more pronounced in humic acids treatments than that in biochar ones. Also, the higher the application rate of conditioners, the higher the grain yield of both wheat and corn plants. It is worth to notice that such increases were coincided with EC and $\mathrm{Na}$ reduction, (Table 4) as well as the increase of organic matter, total $\mathrm{N}$ and available nutrients, (Table 5). 
TABLE 5. Effect of the applied conditioners on some soil nutrient concentrations

\begin{tabular}{|c|c|c|c|c|c|c|c|}
\hline \multirow{2}{*}{ Treatments } & \multirow{2}{*}{ Control } & \multicolumn{3}{|c|}{ Biochar (ton./fed.) } & \multicolumn{3}{|c|}{ Humic acids (Kg/fed.) } \\
\hline & & 5 & 10 & 20 & 5 & 10 & 20 \\
\hline \multicolumn{8}{|c|}{ O.M (\%) } \\
\hline Recent application & 0.49 & 0.60 & 0.61 & 0.63 & 0.65 & 0.71 & 0.97 \\
\hline Residual effect & 0.49 & 0.53 & 0.55 & 0.59 & 0.56 & 0.67 & 0.83 \\
\hline \multicolumn{8}{|c|}{ Total N (\%) } \\
\hline Recent application & 0.11 & 0.13 & 0.13 & 0.14 & 0.15 & 0.16 & 0.17 \\
\hline Residual effect & 0.10 & 0.12 & 0.12 & 0.13 & 0.14 & 0.15 & 0.16 \\
\hline \multicolumn{8}{|c|}{ Available P (ug/g) } \\
\hline Recent application & 10.25 & 11.12 & 13.23 & 15.18 & 17.35 & 20.14 & 23.25 \\
\hline Residual effect & 9.91 & 10.11 & 12.20 & 14.62 & 14.82 & 16.54 & 19.66 \\
\hline \multicolumn{8}{|c|}{ Available K (ug/g) } \\
\hline Recent application & 85 & 96 & 118 & 132 & 123 & 145 & 152 \\
\hline Residual effect & 77 & 82 & 95 & 110 & 98 & 123 & 133 \\
\hline \multicolumn{8}{|c|}{$\mathrm{Fe}(\mathrm{ug} / \mathrm{g})$} \\
\hline Recent application & 30.30 & 41.90 & 57.18 & 63.25 & 61.50 & 72.61 & 82.64 \\
\hline Residual effect & 27.72 & 33.18 & 42.40 & 50.23 & 48.97 & 58.35 & 70.32 \\
\hline \multicolumn{8}{|c|}{ Mn (ug/g) } \\
\hline Recent application & 15.62 & 19.90 & 25.40 & 32.61 & 30.42 & 36.50 & 45.35 \\
\hline Residual effect & 13.22 & 16.36 & 19.51 & 24.33 & 23.90 & 26.31 & 30.21 \\
\hline \multicolumn{8}{|c|}{$\mathrm{Zn}(\mathrm{ug} / \mathrm{g})$} \\
\hline Recent application & 1.95 & 2.18 & 3.25 & 4.65 & 3.11 & 4.32 & 5.12 \\
\hline Residual effect & 1.78 & 1.82 & 1.98 & 2.12 & 1.95 & 2.27 & 3.18 \\
\hline \multicolumn{8}{|c|}{$\mathrm{Cu}(\mathrm{ug} / \mathrm{g})$} \\
\hline Recent application & 0.97 & 1.12 & 1.55 & 1.64 & 1.53 & 1.69 & 1.81 \\
\hline Residual effect & 0.89 & 0.92 & 1.08 & 1.50 & 0.95 & 1.20 & 1.58 \\
\hline
\end{tabular}

TABLE 6. Yield and nutrients content of wheat and corn grains as affected by the applied conditioners

\begin{tabular}{|c|c|c|c|c|c|c|c|c|}
\hline \multirow{2}{*}{ Treatments } & \multirow{2}{*}{ Control } & \multicolumn{3}{|c|}{ Biochar (ton./fed.) } & \multicolumn{3}{|c|}{ Humic acids (Kg/fed.) } & \multirow{2}{*}{$\begin{array}{c}\text { LSD at } \\
\mathbf{5 \%}\end{array}$} \\
\hline & & 5 & 10 & 20 & 5 & 10 & 20 & \\
\hline \multicolumn{9}{|c|}{ Grain yield (ton./fed.) } \\
\hline Wheat & 1.95 & 2.12 & 2.42 & 2.58 & 2.27 & 2.58 & 2.72 & 0.031 \\
\hline Corn & 3.45 & 3.66 & 4.21 & 4.52 & 3.65 & 4.23 & 4.75 & 0.271 \\
\hline \multicolumn{9}{|c|}{$\mathrm{N}(\%)$} \\
\hline Wheat & 0.69 & 0.96 & 1.04 & 1.24 & 0.92 & 1.22 & 1.34 & 0.035 \\
\hline Corn & 0.62 & 0.87 & 0.95 & 1.12 & 0.92 & 1.10 & 1.25 & 0.032 \\
\hline \multicolumn{9}{|c|}{$\mathrm{P}(\%)$} \\
\hline Wheat & 0.27 & 0.31 & 0.35 & 0.42 & 0.35 & 0.45 & 0.57 & 0.023 \\
\hline Corn & 0.36 & 0.42 & 0.44 & 0.47 & 0.45 & 0.48 & 0.56 & 0.034 \\
\hline \multicolumn{9}{|c|}{$\mathrm{K}(\%)$} \\
\hline Wheat & 0.51 & 0.58 & 0.61 & 0.56 & 0.58 & 0.63 & 0.68 & 0.040 \\
\hline Corn & 0.48 & 0.51 & 0.53 & 0.55 & 0.51 & 0.55 & 0.62 & 0.026 \\
\hline \multicolumn{9}{|c|}{$\mathrm{Fe}(\mathrm{ug} / \mathrm{g})$} \\
\hline Wheat & 75 & 105 & 124 & 137 & 121 & 142 & 155 & 4.340 \\
\hline Corn & 66 & 73 & 82 & 112 & 95 & 110 & 125 & 3.243 \\
\hline \multicolumn{9}{|c|}{$\mathrm{Mn}$ (ug/g) } \\
\hline Wheat & 27 & 35 & 39 & 44 & 36 & 42 & 46 & 13.435 \\
\hline Corn & 25 & 32 & 35 & 39 & 32 & 37 & 41 & 2.885 \\
\hline \multicolumn{9}{|c|}{$\mathrm{Zn}(\mathrm{ug} / \mathrm{g})$} \\
\hline Wheat & 46 & 51 & 55 & 62 & 50 & 60 & 73 & 2.885 \\
\hline Corn & 40 & 45 & 48 & 48 & 45 & 53 & 65 & 2.386 \\
\hline \multicolumn{9}{|c|}{$\mathrm{Cu}(\mathrm{ug} / \mathrm{g})$} \\
\hline Wheat & 14 & 15 & 19 & 21 & 20 & 22 & 26 & 2.093 \\
\hline Corn & 18 & 19 & 20 & 22 & 21 & 25 & 28 & 3.439 \\
\hline
\end{tabular}

Egypt. J. Soil Sci. 57, No. 1 ( 2017 ) 
The best treatment in this concern was the application of humic acids at the rate of $20 \mathrm{~kg} /$ fed., where the rate of increment in wheat and corn grain yields over the control reached 39.48 and $37.68 \%$, respectively. This positive effect may be attributed to the improvement action of the applied materials on soil physical properties as well as on the nutrients status in the soil which enhances plant growth, El Sanat (2003). Also, it may be due to the presence of essential nutrients in such materials which increased the metabolic activity of plant, Gupta (2005) as well as the direct effect of humic acids on solubilization and transport of nutrients which ultimately affect the plant productivity, Zaghloul et al., (2009). Morever, it may attributed to the increase in soil nutrient content and uptake of nutrients by plants as well as higher organic matter in the ash, Awodun et al., (2007). These results are in agreement with those reported by (Norman et al., 2004 and Steiner et al., 2007).

\section{Effect of the applied conditioners on nutrients content of wheat and corn grains:}

Nitrogen, phosphorus and potassium are of the integral components in plant metabolism. They are the key constituents of chlorophyll biosynthesis, protein, nucleic acids and other constituents. Data in Table 6 indicate that N, P and $\mathrm{K}$ concentrations in wheat and corn grains significantly increased by the application of all the experimental treatments. It is also clear that the values of such nutrients were higher under the humic acids applications than the biochar ones. The best treatment in increasing $\mathrm{N}, \mathrm{P}$ and $\mathrm{K}$ was the application of humic acids at the rate of $20 \mathrm{~kg} /$ fed., as the rate of increment over the control due to such treatment reached $94.20,111.11$ and 33.33 for $\mathrm{N}, \mathrm{P}$ and $\mathrm{K}$ concentrations in wheat grains, respectively. The respective values for corn grains were $101.61,55.55$ and $29.17 \%$. Data in Table 6 also indicate that $\mathrm{Fe}, \mathrm{Mn}, \mathrm{Zn}$ and $\mathrm{Cu}$ concentrations in wheat and corn grains significantly increased by the application of all experimental treatments. It is also clear that the values of such nutrients took the same trends previously mentioned for $\mathrm{N}, \mathrm{P}$ and $\mathrm{K}$ concentrations in wheat and corn grains. The highest increases of $\mathrm{Fe}, \mathrm{Mn}, \mathrm{Zn}$ and $\mathrm{Cu}$ concentrations in wheat grains were found with the treatment (20 kg humic acids/ fed.), as the increases reached 106.67, 70.37, 58.70 and $85.71 \%$, respectively. The respective increases in corn grains were $89.39,64.00,62.50$ and $55.56 \%$.
The positive effect of such materials on increasing macro- and micro-nutrients concentrations in wheat and corn grains may be attributed to that those materials act as valuable soil amendments that offer a balanced nutritional release pattern to plants, providing nutrients in readily available form that can be easily taken up by plants, Ferreras et al., (2006). Furthermore, humic acids have been reported to enhance mineral nutrient uptake by plants, because it affects the. permeability of root membranes (Türkmen et al., 2004). These results are in agreement with those obtained by Mesut et al. (2010).

\section{Economical evaluation}

Data in Table $7(a, b, c)$ reveal assessment of the experimental inputs and output as will as the ratio between them for each treatment, introducing investment ratio (IR) under the condition of ElTina Plain area . Investment ratio was calculated from output/input analysis of variance for the data, as mentioned by Snedecor and Cochran (1982).

The data indicated the progressive increment in IR by increasing recent application rate and residual effect rate. The application of humic acids led to highest IR for all the two seasons as compared with biochar application, where the IR values under humic acids reached 1.57, 0.74, 1.55 and 0.60 for wheat grains, wheat straw, corn grains and corn shoot respectively. The respective IR values under biochar application were 1.64 , $0.66,1.52$ and 0.59 .

Concerning the effect of recent application and residual effect, it is clear that IR value under recent application (4.8) was higher than that under residual effect (4.26).

\section{Conclusion}

Results of the current study indicated the beneficial application of biochar and humic acids recently suggested as a sustainable means to promote the revegetation and the restoration of degraded lands. Morever, the use of such organic materials as a partial substitution of the chemical fertilization, logically protect the environment from chemical pollution and its hazards on human and animal health. In the same time, produced higher yields and improved soil characteristics. 
TABLE 7a. The prices of all agricultural management inputs under the condition of field experiment according to market price

\begin{tabular}{|c|c|c|}
\hline Economic item & $1^{s t}$ Season for wheat & $2^{\text {nd }}$ Season for corn \\
\hline Biochar & $5 \times 100=500$ & - \\
\hline Price to ton 100 (L.E) & $\begin{array}{l}10 \times 100=1000 \\
20 \times 100=2000\end{array}$ & $\begin{array}{ll}- & \\
-\end{array}$ \\
\hline Humic acids & $5 \times 25=125$ & - \\
\hline Price to $\mathrm{kg} 25$ (L.E) & $\begin{array}{l}10 \times 25=250 \\
20 \times 25=500 \\
\end{array}$ & $\begin{array}{l}- \\
- \\
\end{array}$ \\
\hline Agriculture rent & 2000 & 2000 \\
\hline Irrigation water energy & 500 & 500 \\
\hline Management operation & 500 & 500 \\
\hline Man power & 500 & 500 \\
\hline Seeds & 490 & 840 \\
\hline Pesticides and herbicides & - & - \\
\hline Mineral fertilizations & 365 & 365 \\
\hline Total & 8730 & 4705 \\
\hline & \multicolumn{2}{|c|}{13435} \\
\hline
\end{tabular}

Biochar (price of ton $=100$ pounds). Humic acids (price of $\mathrm{kg}=25$ pounds)

TABLE 7b. Production of both wheat and corn with prices

\begin{tabular}{|l|c|c|c|c|c|c|c|c|c|}
\hline \multirow{2}{*}{ Productions } & \multirow{2}{*}{ Control } & \multicolumn{3}{c|}{ Biochar (ton/fed.) } & \multicolumn{3}{c|}{ Humic acids (ton/fed.) } & \multirow{2}{*}{$\begin{array}{c}\text { Kg Price } \\
\text { (L.E) }\end{array}$} \\
\cline { 4 - 11 } & & $\mathbf{5}$ & $\mathbf{1 0}$ & $\mathbf{2 0}$ & $\mathbf{5}$ & $\mathbf{1 0}$ & $\mathbf{2 0}$ & \\
\hline \multirow{3}{*}{ Wheat } & Grain & 1.95 & 2.12 & 2.42 & 2.58 & 2.27 & 2.58 & 2.72 & 3.10 \\
\cline { 2 - 11 } & Straw & 2.33 & 2.70 & 2.90 & 3.34 & 3.10 & 3.34 & 3.57 & 1.00 \\
\hline \multirow{2}{*}{ Corn } & Grain & 3.45 & 3.66 & 4.21 & 4.52 & 3.65 & 4.23 & 4.75 & 1.65 \\
\cline { 2 - 10 } & Shoot & 4.85 & 5.11 & 5.38 & 5.42 & 5.09 & 5.31 & 5.62 & 0.50 \\
\hline
\end{tabular}

TABLE 7c. Economical evaluation of experimental treatments of El-Tina Plain aerie conditions

\begin{tabular}{|c|c|c|c|c|c|c|}
\hline & & \multirow{2}{*}{$\begin{array}{c}\text { Economic } \\
\text { parameters }\end{array}$} & \multicolumn{2}{|c|}{$1^{\text {st }}$ Season for wheat } & \multicolumn{2}{|c|}{$2^{\text {nd }}$ Season for corn } \\
\hline & & & Grains & Straw & Grains & Shoot \\
\hline \multirow{6}{*}{ Biochar } & 5 & Output & 6572 & 2700 & 6039 & 2555 \\
\hline & 10 & Output & 7502 & 2900 & 6946 & 2690 \\
\hline & 20 & Output & 7998 & 3340 & 7458 & 2710 \\
\hline & & Total Input & 13435 & 13435 & 13435 & 13435 \\
\hline & & Total output & 22072 & 8940 & 20443 & 7955 \\
\hline & & IR & 1.64 & 0.66 & 1.52 & 0.59 \\
\hline \multirow{6}{*}{ Humic acids } & 5 & Output & 7037 & 3100 & 6022 & 2545 \\
\hline & 10 & Output & 7998 & 3340 & 6979 & 2650 \\
\hline & 20 & Output & 8432 & 3570 & 7837 & 2810 \\
\hline & & Total Input & 13435 & 13435 & 13435 & 13435 \\
\hline & & Total output & 23467 & 10010 & 20838 & 8005 \\
\hline & & IR & 1.75 & 0.74 & 1.55 & 0.60 \\
\hline \multicolumn{2}{|c|}{ Investment Ratio } & IR & 3.39 & 1.41 & 3.07 & 1.19 \\
\hline
\end{tabular}

Egypt. J. Soil Sci. 57, No. 1 ( 2017 ) 


\section{References}

A.O.A.C. (1995) Official Methods of Analysis. $15^{\text {th }} \mathrm{ed}$. Association of agriculture chemists. Washington, D.C, U.S.A.

Abd E1-A1, F.S., Shafeek, M.R. Ahmed, A.A. and Shaheen, A.M. (2005) Response of growth and yield of onion plants to potassium fertilizer and humic acid. J. Agric. Sci. Mansoura Univ., Egypt, 30 (1), 441452-.

Angelova, V.R., Akova, V.I., Artinova, N.S. and Ivanov, K.I. (2013) The effect of organic amendments on soil chemical characteristics. Bulgarian J. Agric. Sci., 19 (5), 958971-.

Arancon, N.Q., Edwards, C.A., Lee, S. and Byrne, R. (2006) Effects of humic acids from vermicomposts on plant growth. European J. Soil Biol., 42, 6569-.

Awodun, M.A., Ojeniyi, S.O. Adeboye, A. and Odedina, A.S. (2007) Effect of oil palm bunch refuse ash on soil and plant nutrient composition and yield of maize. Eurasian J. Sustainable Agric., 1, 50-54.

Bhattacharjee, G.; P. S. Chaudhuri and M. Datta (2001). Response of paddy (Var. TRC- 87251-) crop on amendment of the field with different levels of vermicompost. Asian J. Microbial. Biotech. Environ. Sci., 3, 191196-

Black, C.A. (1982) Methods of Soil Analysis, Part 2, Amer. Soc. Agron. Madison, Wisconsin, USA.

Brodowski, S., Amelung, W. Haumaier, L. Abetz, C. and Zech, W. (2005) Morphological and chemical properties of black carbon in physical soil fractions as revealed by scanning electron microscopy and energy-dispersive x-ray spectroscopy. Geoderma, 128, 116-129

Chen, Y., Clapp, C.E. and Magen, H. (2004a) Mechanisms of plant growth stimulation by humic substances: The role of organo-iron complexes. Soil Sci. Plant Nutr., 50, 1089-1095.

Chen, Y., De Nobili, M. and Aviad, T. (2004b). Stimulatory effects of humic substances on plant growth. In: Magdoff FR, Weil R, (Ed.) Soil organic matter in sustainable agriculture. Boca Raton, CRC Press, FL, USA: 103-129.

Cheng, C. H., Lehmann, J. and Engelhard, M.H. (2008) Natural oxidation of black carbon in soils: Changes in molecular form and surface charge along a climosequence. Geochem., Cosmochim. Ac., 72, $1598-1610$
Cheng, C.H., Lehmann, J. Thies, J.E. Burton, S.D. and Engelhard, M.H. (2006) Oxidation of black carbon by biotic and abiotic processes. Org. Geochem., 37, $1477-1488$

Cottenie, A., Verloo, M. Kiekens, L. Velghe, G. and Camerlynck, R. (1982) Chemical Analysis of Plants and Soils. Laboratory of analytical and agrochemistry. State Univ., Ghent, Belgium.

Dhanushkodi, V. and Subrahmaniyan, K. (2012) Soil management to increase rice yield in salt affected coastal soil - A Review. Int. J. Res. Chem. Environ., $2,1-5$.

Dias, B.O., Silva, C.A. Higashikawa, F.S. Roig, A. and Sanchez- Monedero, M.A. (2010) Use of biochar as bulking agent for the composting of poultry manure: Effect on organic matter degradation and humification. Bioresour. Technol., 101, 1239-1246

Ebhin Masto, R.; Md. A. Ansari; J. George; V.A. Selvi and L.C. Ram (2013) Co-application of biochar and lignite fly ash on soil nutrients and biological parameters at different crop growth stages of Zea mays. Ecological Engineering, 58, 314322-.

El-Fayoumy, M.E. and H.M. Ramadan (2002) Effect of bio-organic manures on sandy soils amelioration and peanut productivity under sprinkler irrigation system. Egypt. J. Soil Sci., 42, 838.415.

El Sanat, G.M. (2003) Effect of amelioration processes on nutrients status in salt affected soils. M. Sc. Thesis, Fac. Agric. Menufiya Univ., Egypt.

Ferreras, L., Gomez; S. Toresani, Firpo, I. and Rotondo, R. (2006) Effect of organic amendments on some physical, chemical and biological properties in a horticultural soil. Bioresour. Technol., 97, 635-640.

Gupta, P.K. (2005) Vermicomposting for sustainable agriculture. Bharat Printing Press, Jodhpur, India: 11-14.

Hafez, M. Magda (2003) Effect of some sources of nitrogen fertilizer and concentration of humic acid on the productivity of squash plant. Egypt J. Appl. Sci. 19(10), 293309-.

Khalil, Heba, M.A., Afifi, M.M.I. El-Akshar, Y.S. and El-Sayed, G.A.M. (2013) Effect of bio- organic fertilizers on barley plants in a saline soil. J. Appl. Sci. Res., 9, 53375343-.

Khan, A.; Gurmani, A.L.I.R. Khan, M.Z. Hussain, F. Akhtar, M.D. and Khan, S. (2012) Effect of humic acid on the growth, yield, nutrient composition, photosynthetic pigment and total sugar contents of peas (Pisum sativum L.). J. Chem. Soc. of Pakistan, 


\section{$1,1-7$.}

Mesut, K., Önder, T. Metin, T. and Burcu, T. (2010) Phosphorus and humic acid application alleviate salinity stress of pepper seedling. African $J$. of Biotechnol. 9, 58455851-.

Mora, V., Bacaicoa, E. Zamarreno, A.M. Aguirre, E. Garnica M. Fuentes, M. and Garcia-Mina, J.M. (2010) Action of humic acid on promotion of cucumber shoot growth involves nitraterelated changes associated with the root-to-shoot distribution of cytokinins, polyamines and mineral nutrients. J. Plant Physiol., 167 633-642.

Nardi, S., Sessi, E. Pizzeghello, D. Sturato, A. Rella, R. and Parvoli, G. (2002) Biological activity of soil organic matter mobilized by root exudates. Chemosphere, 46, 10751081-.

Norman, Q., Stephenlesa, A. Edwardsa, C.A. and Atiyeh, R. (2004) Effect of humic acid derived from cattle, food and paper -waste vermicomposts on growth of greenhouse plants. The Soil Ecology Laboratory, Ohio State Univ., USA.

Pitman, M.G. and Läuchli, A. (2004) Global impact of salinity and agricultural ecosystems. In: A. Läuchli and U. Lüttge (Ed.). Salinity: environment plants molecules. Springer, Netherlands.

Ramoliya, P.J. and Pandey, A.N. (2003) Effect of salinisation of soil on emergence, growth and survival of seedlings of Cordia rothii. Forest Econ. \& Mgt., 176,185194-

Renard, D., Iriarte J. Birk, J. J. S. Rostain, B. Glaser and D. McKey (2012) Ecological engineers ahead of their time: The functioning of preColumbian raised-field agriculture and its potential contributions to sustainability today. Ecol. Eng., 45, $30-44$.

Rodriguez-Navarro, A. and Rubio, F. (2006) Highaffinity potassium and sodium transport systems in plants. J. Exp. Bot., 57, $1149-1160$.

Scheuner, E. T., Makeschin, F. Wells, E.D. and Carter, P.Q. (2004) Short-term impacts of harvesting and burning disturbances on physical and chemical characteristics of forest soils in western Newfoundland, Canada. European J. Forest Res., 123, 321330-

Senesi, N. and Plaza, C. (2007) Role of humification processes in recycling organic wastes of various nature and sources as soil amendments. Clean Soil, Air, Water, 35, 26-41

Shankar, K. Sreedevi, S. Sumathi, M. Shankar and Reddy, N. N. (2012) Comparison of nutritional quality of organically versus conventionally grown

Egypt. J. Soil Sci. 57, No. 1 ( 2017 ) tomato. Indian J. of Hort., 69 (1), 8690-

Snedecor, G.W. and Cochran, W.G. (1982) In "Statistical methods." $7^{\text {th }}$ ed. Iowa State Univ. Press, USA.

Steiner, C., Teixeira, W. Lehmann, J. Nehls, T. Vasconcelos, J. de Macêdo; Blum, W. and Zech, W. (2007) Long term effects of manure, charcoal and mineral fertilization on crop production and fertility on a highly weathered Central Amazonian upland soil. Plant and Soil, 291, 275290-.

Tejada, M. and J.L. Gonzalez (2006) Relationships between erodibility and erosion in a soil treated with two organic amendments. Soil Till. Res., 91, 186198-.

Turkmen, O., Dursun, A. Turan, M. and Erdinc, C. (2004) Calcium and humic acid affect seed germination, growth, and nutrient content of tomato (Lycopersicon esculentum L.). Seedlings in saline Soil Conditions. Acta Agric. Scand., Sect. B, Soil \& Plant Sci., 54, 168174-

Uzoma, K.C., Inoue, M. Andry, H. Fujimaki, H. Zahoor, A. and Nishihara, E. (2011) Effect of cow manure biochar on maize productivity under sandy soil condition. Soil Use Manag., 27(2), 205212-.

Woolf, D.; Amonette, J.E. Street-Perrott, F.A. Lehmann, J. and Joseph, S. (2010) Sustainable biochar to mitigate global climate change. Nature Commun, 156, 147-.

Zaghloul, S. M., El-Quesni, F.E.M. and Mazhar, A.A.M (2009) Influence of potassium humate on growth and chemical constituents of Thuja orientalis L seedlings. Ozean J. Appl. Sci., 2, 7378-.

( Received: 8/8/2016; accepted:26/10/2016) 
أثر استخدام بعض محسنات التربة على صفات و انتاجية الاراضى المتأثرة بالأملاح بمنطقة سهل الطينة , شمال سيناء ، مصر. قزمع صبانة الأر اضى موسى ـ مركز بحوث الصحر اء ــ المطرية ـ القاهرة

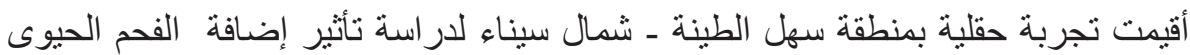

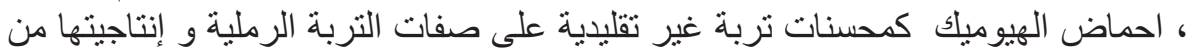
محصولى القمح و الذرة الثنامية.

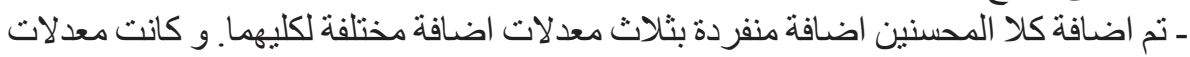
الإضافة للفحم الحيوى 5 ، 10 ، 20 طن / فدان و لأحماض الهيوميك 5 ، 10 ، 20كجم /

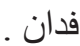
أوضحت النتائج المتحصل عليها ما يلي :

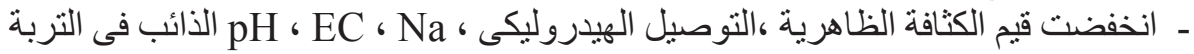

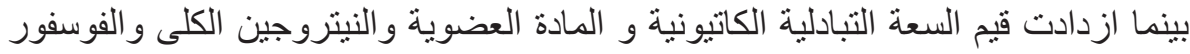

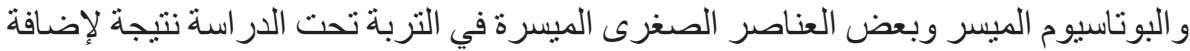

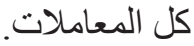

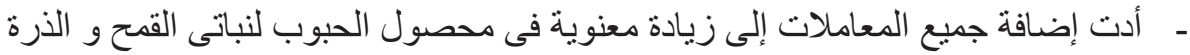

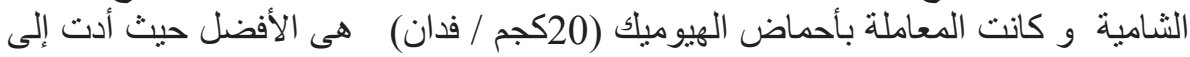

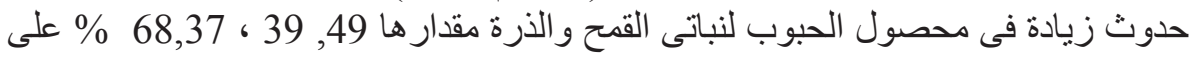

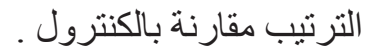

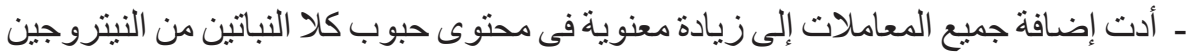

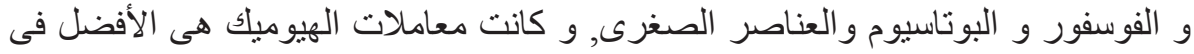

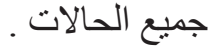

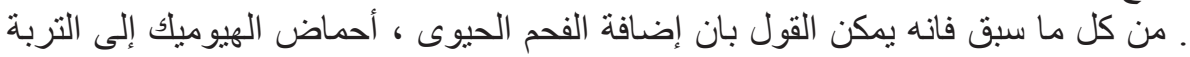

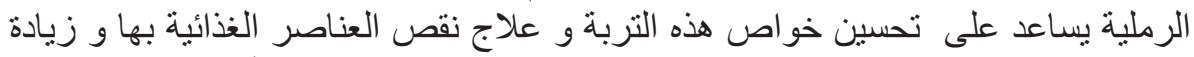

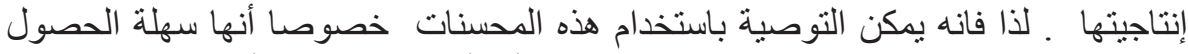

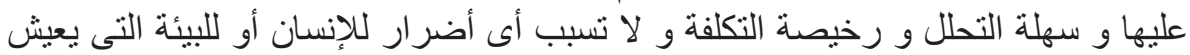
الكلمات الدالة: الفحم الحيوى ـ أحماض الهيوميك ـ الأر اضى المتأثرة بالأملاح - محصول

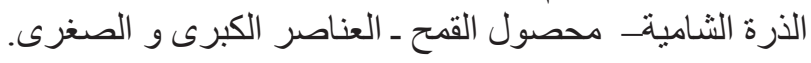

